environmental assessment studies, mollusk samples from a tropical estuary (Pina Bay, Pernambuco, Brazil) were analyzed. The results show that some species concentrate some element relative to others, probably as a consequence of each species feeding habit. Even though there is no specific legislation regarding metal concentration in seafood in Brazil, the results show that metal concentrations do not exceed international limits, except for $\mathrm{V}$, which exceeded the EPA risk level. Pina Bay is highly impacted by sewage discharges but the metal concentration in the mollusk populations do not seems to cause a threat to human consumption. The results also suggest that the semi-quantitative method could be used as a screening method in environmental impact assessment studies. - (May 24, 2002 ) .

\section{TECTONIC EVOLUTION OF THE ASUNCIÓN RIFT, EASTERN PARAGUAY}

Claudio Riccomini, Victor F. VelázQuez,

Celso B. Gomes, Anderson Milan and

Alethéa E. M. SAllun

Instituto de Geociências, Universidade de São Paulo, 05508900 São Paulo, SP, Brazil.

The Asunción Rift is an important tectonic feature of Mesozoic-Cenozoic age in eastern Paraguay. With a width between 25 and $40 \mathrm{~km}$, this structure consists of three segments: the well-defined western segment with a NW-SE strike and extending over $90 \mathrm{~km}$ between Benjamin Aceval and Paraguarí; the central E-W segment of about 70 $\mathrm{km}$ in extent linking the cities of Paraguarí and Villarrica; and the less-defined eastern segment, $40 \mathrm{~km}$-long, with a NW-SE strike, between Villarrica and the Cordillera del Ybytyruzú.

Tectonic studies in the region revealed a first phase of faulting during the Early Cretaceous associated with tholeiitic magmatism in the eastern segment of the rift and followed by expressive alkaline (potassic) magmatism mainly in the central segment of the rift. Structural analysis of diabase and alkaline dyke swarms indicated the action of a paleostress field with $\sigma 1$, NW-SE oriented /horizontal, $\sigma 2$ vertical, and $\sigma 3 \mathrm{NE}-\mathrm{SW} /$ horizontal, related with an E-W oriented, right-lateral strike-slip binary.

During the Paleocene, the western segment of the rift was filled by fanglomeratic, aeolian and volcaniclastic deposits of the Patiño Fm. Deep NW-trending lithospheric faults served as conduits for ultra-alkaline rocks, of nephelinitic composition, bearing spinel lherzo- lite mantle xenoliths. These rocks intruded the still unlithified sediments of the Patiño Fm. causing synsedimentary hydrothermal silicification. This fact and the presence of volcanic fragments (bombs and lapilli) indicates that the Patiño Fm. represents the sedimentary record associated with tectonic and magmatic episodes that occurred in the Asunción Rift during the Paleogene. Structural analysis of nephelinitic plugs, necks and dikes indicated a paleostress field with $\sigma 1$, NW-SE/horizontal, $\sigma 2$ vertical, and $\sigma 3 \mathrm{NE}-\mathrm{SW} /$ horizontal, also related with an E-W oriented right-lateral strike-slip binary.

Quaternary faulting, recorded in the western segment of the rift, shows a stress field with $\sigma 3$ horizontal along the E-W direction, probably responsible for the installation of the Ypacaraí Graben and the morphological compartmentalization of the region. - (May 24, 2002 ).

*E-mail: riccomin@usp.br

\section{AN INTEGRATED IDTIMS, EVTIMS AND SHRIMP ZIRCON DATING STUDY}

\section{Kei SATo}

Instituto de Geociências, Universidade de São Paulo, 05508900 São Paulo, SP, Brazil.

Presented by Valderez P. Ferreira

An integrated IDTIMS (isotope dilution thermal ionization mass spectrometry), EVTIMS (evaporation thermal ionization mass spectrometry) and SHRIMP (Sensitive High Mass Resolution Ion Microprobe) study of Archean orthogneiss reworked in the Brasiliano orogeny is discussed here. The sample comes from the Atuba Complex, near Curitiba, Paraná State.

Zircon age determination by three methods are $3055 \pm 90$ (IDTIMS upper concordia intercept), $3000 \pm$ $40 \mathrm{Ma}$ (EVTIMS ${ }^{207} \mathrm{~Pb} /{ }^{206} \mathrm{~Pb}$ plateau) and $3079 \pm 23 \mathrm{Ma}$ (SHRIMP). These results are in good agreement.

The SHRIMP analysis guided by cathodoluminescence (CL) also recognized younger age (e.g. ca. 2920 Ma, 2200 Ma and $800 \mathrm{Ma}$ ) events in the growth/evolution of the zircons. The petrography of the zircons revealed by the CL images also clearly demonstrated that $3000-3100 \mathrm{Ma}$ zircon population is igneous oscillatory-zoned zircon, and is not an inherited component in a younger rock. Thus it is clear that MJ316 is a Mesoarchean rock.

The EVTIMS, "step heating", of one of the studied zircons showed that ${ }^{207} \mathrm{~Pb} /{ }^{206} \mathrm{~Pb}$ date rises from ca. 
$2350 \mathrm{Ma}$ at $1370^{\circ} \mathrm{C}$ to reach a plateau equivalent to ca. $3000 \mathrm{Ma}$ from $1420^{\circ} \mathrm{C}$. This in accord with an event at ca. 2200 Ma seen in the SHRIMP data, where there would have been not only development of partial overgrowths but also variable loss of some radiogenic $\mathrm{Pb}$ from "damaged" ca. 3000 Ma zircon as well.

The IDTIMS study involved analysis of multigrain unabraded aliquots and also leached grains, now know from CL images to be structural complex. The upper concordia intercept (3055 Ma) can only be considered as an "average", indicating an important component of Mesoarchean zircons. Two leaching phases yielded close to concordant dates at ca. $2390 \mathrm{Ma}$-in agreement with the more interpretable SHRIMP indications of ca. $2200 \mathrm{Ma}$. zircon growth/thermal disturbance.

It is considered that in this complex rock it is fortuitous that IDTIMS, EVTIMS and SHRIMP results give essentially the same protholith ages. In the other cases in the literature where there have been comparative EVTIMS/IDTIMS - SHRIMP studies of geologically complex samples with structurally complex zircons, dates by the methods do not always agree. However, when geologically simple samples are dated by the different methods the results are generally in good agreement. - ( May 24, 2002 )

\footnotetext{
*E-mail: keisato@usp.br
}

\section{C-ISOTOPE COMPOSITION OF EARLY PALEOPRO- TEROZOIC CARBONATES FROM THE MINAS SUPER- GROUP AND THE RECORD OF THE LOMAGUNDI PHE- NOMENON IN BRAZIL}

Alcides N. Sial ${ }^{1}$, Valderez P. Ferreira ${ }^{1}$ and

Antonio W. Romano ${ }^{2}$

${ }^{1}$ NEG-LABISE, Department of Geology, UFPE, Cx. Postal 7852, 59732-970 Recife, PE, Brazil

${ }^{2}$ Institute of Geosciences, UFMG, 30430-120 Belo Horizonte, MG, Brazil.

The Paleoproterozoic $\delta^{13} \mathrm{C}_{\text {carb }}$ positive excursion (2.25-2.05 Ga; Lomagundi phenomenon) has a global character, but no occurrence in South America has been registered. This study reports, by the first time, this C isotope anomaly in Brazil, in the early Paleoproterozoic, marine carbonates of the Fecho do Funil Fm., Minas Supergroup.

The 2.42 Ga-old Gandarela Fm. consists of red carbonate BIF at the base of the sequence (Minas Super- group), gradually replaced upwards by buff dolomites, and limestones, locally stromatolitic, in light and darkgray alternating bands. Carbonates display $\delta^{13} \mathrm{C}_{\text {carb }}$ from -1.6 to $+0.4 \%$ o $\mathrm{PDB}(\mathrm{n}=58)$, the most negative values found in red dolomites in contact with the underlying, finely laminated, Cauê banded iron formations. Gandarela carbonates from the Heargraves quarry yielded $\delta^{13} \mathrm{C}_{\text {carb }}$ from -1.4 to $-0.6 \% \circ \mathrm{PDB}$ ( $\left.\mathrm{n}=28\right)$.In the Cercadinho Fm., at the base of the Piracicaba Group, $\delta^{13} \mathrm{C}_{\text {carb }}$ varies from +3.3 to $+4.2 \%$ PDB $(\mathrm{n}=10)$, values decreasing erratically with depth.

The Fecho do Funil dolomites $(2.11 \pm 0.11 \mathrm{Ga}$, deformation/metamorphic age) were probably deposited within the time span for the Lomagundi positive excursion age of the Kaapval craton, Africa. The sampled section of this Formation consists, at the base, by finegrained, stromatolite-rich white and pink dolostones, and then by fine-grained white marble. Stratigraphically collected samples show $\delta^{13} \mathrm{C}_{\text {carb }}$ remarkably homogeneous $(+6.0$ to $+6.5 \% \circ \mathrm{PDB}, \mathrm{n}=47)$. The oxygen isotopes are also fairly constant $(-9.7$ to $-10.8 \% \circ \mathrm{PDB})$ and show a trend which is rather antipathetic to the variation in $\mathrm{C}$ isotopes. These high $\delta^{13} \mathrm{C}_{\text {carb }}$ carbonates show little scatter, relatively shallow trend on $\delta^{13} \mathrm{C}$ vs $\delta^{18} \mathrm{O}$ diagram and are consistent with low-grade metamorphic decarbonation. The elevated $\mathrm{C}$-isotope values were least reset and probably reflect their protolith composition, rather than subsequent diagenetic or metamorphic processes. This Formation is a proxy, in South America, for the global Lomagundi phenomenon.

There is no evidence for the triad early Paleoproterozoic glacial events of the $(2.45-2.25 \mathrm{Ga}$ interval $)$ recognized in North America. C isotope patterns for carbonates of the Minas Supergroup suggest that the Gandarela Fm. was deposited around $2.4 \mathrm{Ga}$; the moderate C positive anomaly of the Cercadinho carbonates suggests deposition around 2.35 and the Fecho do Funil carbonates were deposited probably around $2.2 \mathrm{Ga}$. - (May 24, 2002 ).

\section{A NEW INTERPRETATION ON THE SERGIPANO BELT DOMAIN}

Marinho A. Silva-Filho and Helton H. F. Torres

Companhia de Pesquisa de Recursos Minerais (CPRM), Recife, PE, Brazil.

Presented by AlCides N. Sial

This study deals with newly identified tectonic- 